\title{
Vegetative parameters of sweet cherry (Cerasus avium L.) cultivars in two training systems
}

\author{
Csihon, Á., Dremák P., Vámos, P., Bicskei D. K. \& Holb, I. J. \\ University of Debrecen, Faculty of the Agricultural and Food Sciences and Environmental Management, \\ Institute of Horticulture, 138. Böszörményi str., Debrecen, H-4032, Hungary \\ Author for correspondence: csihonadam@agr.unideb.hu
}

Summary: Hungarian sweet cherry production has been changed recently. Thanks to the favourable selling prices many new plantations were established in the last years. In the new orchards mainly spindle canopy are trained, although many type of crown forms are used all over the world. In our study slender spindle and bush canopy were evaluated with three cultivars ('Petrus', 'Vera', 'Carmen') grafted on Prunus mahaleb rootstock. Vigor of the 3-4 years old trees showed spectacular differences. The highest vigor with Spanish bush was found for cv. 'Vera', but on slender spindle canopy the thickness values were medium. Meanwhile cv. 'Petrus' showed the highest trunk thickness with spindle canopy, but the lowest with Spanish bush. On spindle canopy cv. 'Carmen' presented the highest ramification ability, but its 2-3 years old twigs started to bald very early, which can be considered an unfavorable phenomenon. Bush canopy still can be described with strong vegetative growth on 3-4 years old trees, as vigor of spindle trees are more moderate.

Csihon, Á., Dremák P., Vámos, P., Bicskei D. K., Holb, I. J. (2019): Vegetative parameters of sweet cherry (Cerasus avium L.) cultivars in two training systems. International Journal of Horticultural Science 25(1-2): 42-45. https://doi.org/10.31421/IJHS/25/1$2 . / 2913$

Key words: sweet cherry, canopies, slender spindle, bush, vegetative parameters

\section{Introduction}

Sweet cherry cultivars are mainly used for fresh consumption, therefore intensive canopies are required which facilitate the harvest and help the penetration of light.

Training systems are often adapted to ecological environment. In southern part of Europe an open-center canopy, the Spanish bush is commonly used (Negrón et al., 2005; Bujdosó, 2006), as in Northern-, and Central-Europe different spindle crown forms are widespread (Zahn, 1996; Whiting, 2005; Balmer \& Blanke, 2005). In Hungary free spindle crown form is used safely at all production sites. Training slender spindle and super spindle means risk because of the frosts at blooming (Soltész et al., 2000). Hrotkó (2007) reports that two new training systems are developed and adapted in Hungary in the intensive sweet cherry orchards, namely modified Brunner-spindle and cherry spindle. Gonda et al. (2007) developed also canopies and pruning systems for domestic varieties in intensive orchards. Vaszily \& Gonda (2010) examined training and maintaining of free spindle and slender spindle with different cultivars grafted on Prunus mahaleb rootstocks and found that each cultivar needs special pruning policy in order to produce optimal yields and quality continuously. Bicskei \& Gonda (2014) compared free spindle and bush canopies and stated that bush canopy makes easier the maintaining of the vegetative and generative balance. On the other hand the pruning and the harvest are also easier to carry out thanks to the lower tree height.

Bush canopy is very similar to the peach's crown form, the cauldron. The central axes of the tree must be cut off, as about 4-6 main branches are created during the training period. Thanks to the low trunk the productive surface of the canopy is located close to the ground, so the harvest can be fulfilled easier. Although this means higher risk of late spring frost in some production areas. Training of the canopy doesn't require any supporting system, but keeping the balance of the vegetative and generative growth on vigorous rootstock is more difficult (Hrotkó, 2003).

Tomcsányi (1973) claims that cultivar is a biological mean of production which determines basically the feature of the product. Production value of the cultivars is determined by the growing and the fruit bearing characteristics and the fruit quality in a complex way. Among the features of the cultivars growing characteristics are not detailed in most of the cultivar descriptions, they are handled just superficially (Csihon, 2015; Csihon et al. 2015).

The objective of this study was to evaluate vegetative characteristics of three sweet cherry cultivars ('Carmen', 'Vera' and 'Petrus') with two training systems (slender spindle and bush canopy).

\section{Materials and methods}

Observations were performed at the University of Debrecen, Pallag Experimental Station of Horticulture in 20152016. Orchard was planted in March of 2012, trees were grafted on $P$. mahaleb rootstock. Spacing between and within rows was $5.0 \times 2.5 \mathrm{~m}$. Three domestic breaded cultivars were involved to the examinations ('Petrus', 'Vera' and 'Carmen'), which pollinate each other well.

Direction of the rows is North-West - South-East. Water supply is provided by dripping irrigation system, which suitable also for nutrient supply. 
Ecological parameters of the experimental site are shown in Table 1. Average precipitation of the area is $500-550 \mathrm{~mm}$. Mean temperature of a year is $10-11^{\circ} \mathrm{C}$. Orchard soil type is slightly acidic ( $\mathrm{pH}$ 6.1-5.5), sandy with low humus content (Hu\% 1.17-1.01). Macronutrient contents of the soil is suitable for fruit growing.

Table 1. Ecological parameters of the experimental site (Debrecen-Pallag)

\begin{tabular}{|l|c|c|}
\hline Sum of temperature & \multicolumn{2}{|c|}{$3200-3300{ }^{\circ} \mathrm{C}$} \\
\hline Sunshine hours & \multicolumn{2}{|c|}{2045 hours/year } \\
\hline Mean temperature of a year & \multicolumn{2}{|c|}{$10-11^{\circ} \mathrm{C}$} \\
\hline Precipitation & \multicolumn{2}{|c|}{$500-550 \mathrm{~mm}$} \\
\hline \multicolumn{2}{|c|}{ The soil is light sandy } \\
\hline & $\mathbf{0 - 3 0} \mathbf{~ m}$ & $\mathbf{3 0 - 6 0} \mathbf{~ m}$ \\
\hline pH & 6.1 & 5.5 \\
\hline “Arany" number of heaviness & 26 & 26 \\
\hline Humus content (\%) & 1.17 & 1.01 \\
\hline $\mathbf{P}_{\mathbf{2}} \mathbf{O}_{\mathbf{5}}$ (mg/kg) & 272.3 & 125.7 \\
\hline $\mathbf{K}_{\mathbf{2}} \mathbf{O}$ (mg/kg) & 158.3 & 150.3 \\
\hline
\end{tabular}

Figure 1 shows the precipitation of the experimental site in 2015 and 2016. In a common year precipitation is about 500$550 \mathrm{~mm}$ in Debrecen-Pallag.

It is well visible that there is a significant different between the two years. In 2015, $433 \mathrm{~mm}$ rain was fallen, the highest amount in June, July and August. In 2016 the weather was more wet, precipitation reached $786 \mathrm{~mm}$ in 2016. June (143 $\mathrm{mm})$ and July $(130 \mathrm{~mm})$ were strongly humid.

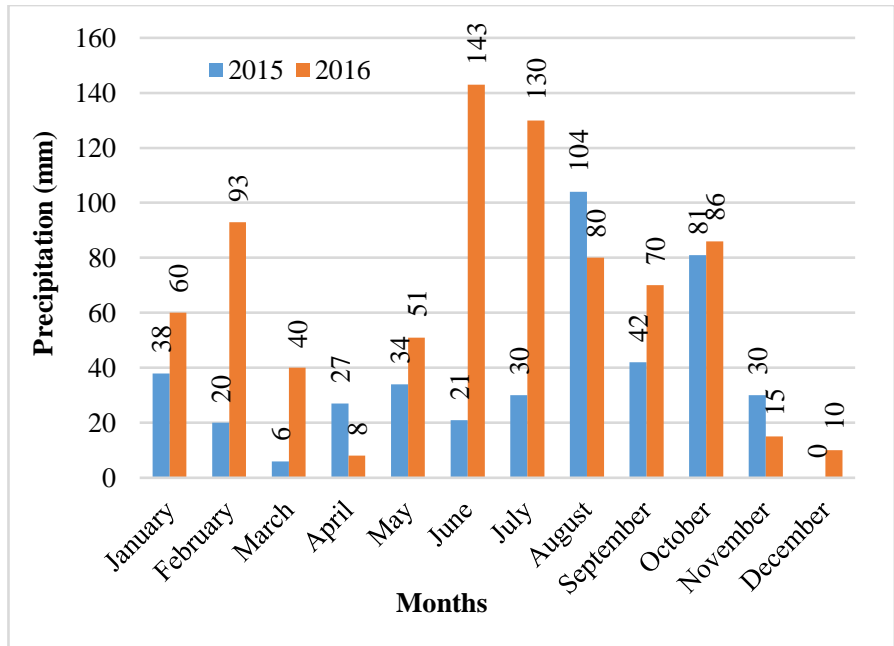

Figure 1. Precipitation of the experimental site (Debrecen-Pallag, 2015-2016)

\section{Measured parameters}

In this study the next parameters are presented:

- thickness of the trunk $\left(\mathrm{cm}^{2}\right)$,

- central axis thickness at 1.0, 1.5 and 2.0 meter height $\left(\mathrm{cm}^{2}\right)$,

- number of primary branches (piece),

- diameter of primary branches $\left(\mathrm{cm}^{2}\right)$,

- $\quad$ shoot length $(\mathrm{cm})$,

- $\quad$ specific shoot number $\left(\right.$ piece $\left./ \mathrm{cm}^{2}\right)$ and

- $\quad$ specific fruiting parts number $\left(\right.$ piece $\left./ \mathrm{cm}^{2}\right)$.

\section{Results and discussion}

Trunk and axis cross section area of the slender spindle canopy is presented in Figure 2, which is a main indicator of the vegetative growth. From economics viewpoint the slimmer trunk thickness is advantageous, as trees bear the first fruits earlier.

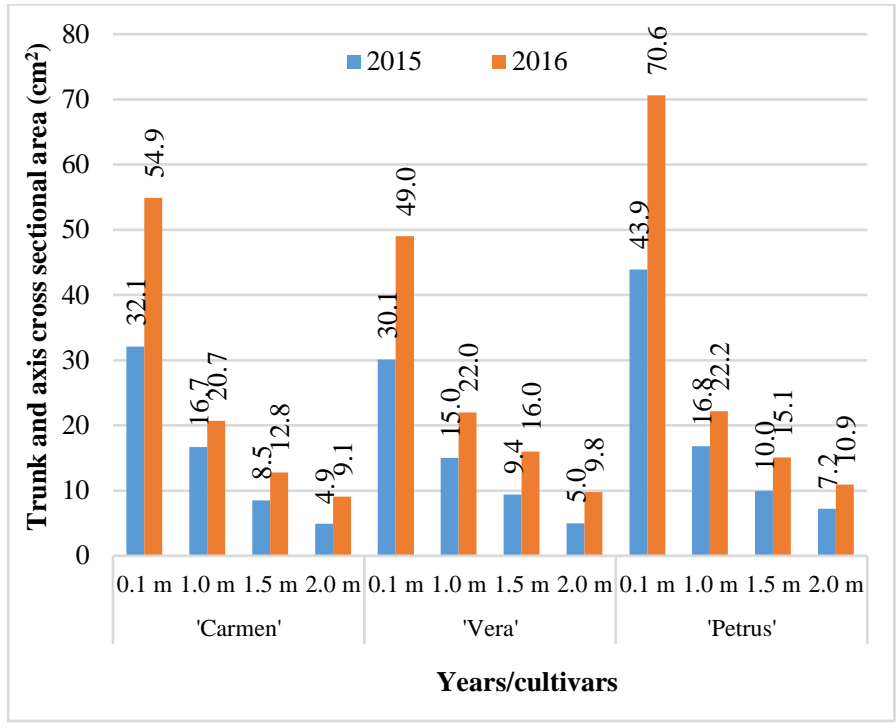

Figure 2. Trunk and central axis cross sectional area at slender spindle canopy (Debrecen-Pallag, 2015-2016)

From the bottom to the top natural slimming can be noticed, but its scale is different for each cultivar, which describe well their characteristics. Cultivar 'Carmen' and 'Vera' showed similar growing peculiarities although cv. 'Carmen' has thicker bottom parts. Cultivar 'Vera' has the thinnest trunk measured $10 \mathrm{~cm}$ high from the ground in both years $\left(30.1\right.$ and $\left.49.0 \mathrm{~cm}^{2}\right)$, while these values are more equalized to the top. At the same time axis thickness of cv. 'Vera' is above the values of cv. 'Carmen' at 2.0 meter high from the ground. Cultivar 'Petrus' has the highest trunk and axis thickness in both years.

Vigor of four, five years old trees showed spectacular differences. Its partly determined by the characteristics of the cultivars, which relates to the growing and fruit bearing potential of the trees. Trunk thickening in the observed period is still strong, 60-70\% increase was recorded at $10 \mathrm{~cm}$ high from the ground.

Figure 3 shows the trunk cross sectional area of the Spanish bush canopy.

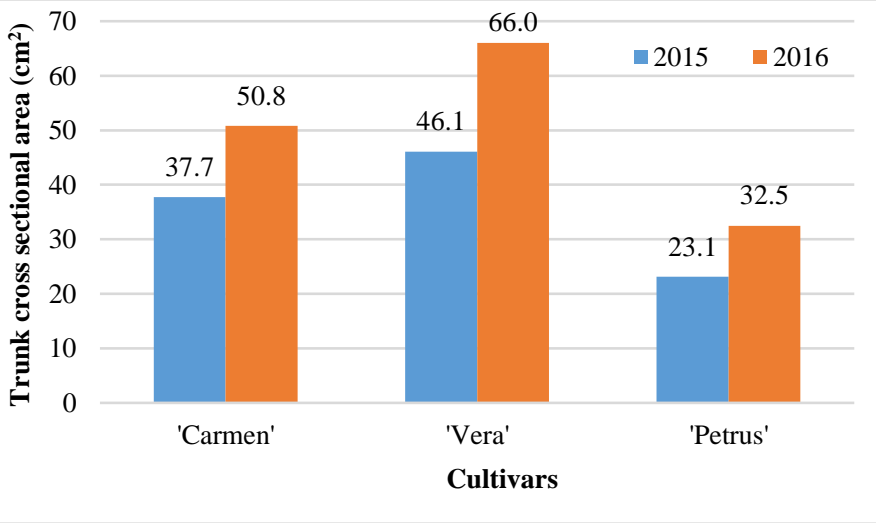

Figure 3. Trunk cross sectional area at Spanish bush canopy in $10 \mathrm{~cm}$ high (Debrecen-Pallag, 2015-2016) 
Thanks to the different training methods of the bush trees trunk thickness growth is higher between 2015 and 2016. Cultivar 'Carmen' showed 34\% increase, cv. 'Vera' presented $43 \%$ growth, while cv. 'Petrus' with the thinnest trunk displayed $41 \%$ increase. Based on this cv. 'Petrus' can be described with more moderate tree sizes compared to the other cultivars, which makes easier the intensive canopy training.

Comparing the two canopies it is interesting that with Spanish bush the highest vigor was found for cv. 'Vera', but on slender spindle canopy the thickness values were medium. Meanwhile cv. 'Petrus' showed the highest trunk thickness with spindle canopy, but the lowest with Spanish bush.

Parameters of shoots, branches and fruit bearing parts on slender spindle canopy are presented in Figure 4.

Notable differences in number of primary branches was not detected during two years. Increasing the number of these branches is not an objective, as in the yielding period presence of the young twigs located on the branches is favorable. Differences of the cultivars can be attributed primarily to the cultivar's property. It can be seen that cv. 'Carmen' reached the highest ramification ability.

Thickness of main scaffold branches increased significantly in the observed years. Cultivar 'Petrus' reached the highest values (3.1-4.1 $\left.\mathrm{cm}^{2}\right)$, but the level of increase was only $32 \%$ in two years. Other two cultivars showed lower data in both years, although the dynamic of the thickening can be up to 2.8 times (cv. 'Vera' with 1.1 and $3.1 \mathrm{~cm}^{2}$ ). In the case of cv. 'Petrus' this parameter can be related with the lower number of branches.

Regarding the average shoot length the order of the cultivars was cvs 'Petrus', 'Vera' and 'Carmen' in descending order. Between the extreme values $60 \%$ different was measured $(75.4$ and $47.4 \mathrm{~cm})$. Higher shoot length of cv. 'Petrus' can be attributed to the fewer number, but thicker branches. Thanks to its moderate ramification ability longer shoots were performed. Order of the cultivars changed in 2016, at the same time the length of shoots decreased significantly. This reduction was $48 \%$ for cv. 'Petrus', $27 \%$ for cv. 'Vera' and only $9 \%$ for cv. 'Carmen'. Accordingly in the case of cv.
'Petrus' the extreme strong shoot growth has already declined favorably.

Specific shoot number (number of shoots calculated to the brunch cross section area) was between 1.1 and 1.6 piece $/ \mathrm{cm}^{2}$ depending on the cultivars in 2015. One year later naturally smaller decrease was observed with this parameter (0.7-1.2 piece $\left./ \mathrm{cm}^{2}\right)$. Cultivar 'Carmen' with the highest ramification ability presented $25 \%$ decrease (from 1.6 to 1.2 piece $/ \mathrm{cm}^{2}$ ).

Productivity of the cultivars is basically determined by the density of the fruit bearing parts (number of fruit bearing parts calculated to the brunch cross section area). Among the cultivars 'Petrus' reached the highest value $\left(5.9 \mathrm{piece} / \mathrm{cm}^{2}\right)$, and cv. 'Carmen' showed the lowest data $\left(4.5\right.$ piece $\left./ \mathrm{cm}^{2}\right)$ in 2015. Next year cv. 'Petrus' displayed 17\% increase (from 5.9 to 6.9 piece $/ \mathrm{cm}^{2}$ ). Cultivar 'Vera' showed outstanding, twofold increment (from 5.0 to $10.4 \mathrm{piece} / \mathrm{cm}^{2}$ ). Cultivar 'Carmen' presented interesting result in term of the production technology, as the density of the fruit bearing decreased with $54 \%$ (from 4.5 to $2.1 \mathrm{piece} / \mathrm{cm}^{2}$ ). Accordingly the 2-3-years-old twigs, which are the most valuable parts of the canopy started to bald with cv. 'Carmen', which can be considered an unfavorable phenomenon.

Parameters of shoots and branches on Spanish bush canopy are shown in Figure 5. Number of the main scaffold branches has minor significance with bush canopy than with slender spindle, as in the first years of the canopy training we cut back the shoots. Thanks for that the cropping surface can be created near to the ground floor. Highest number of branches were counted with cv. 'Vera' (7.6-7.6 piece). The approximate value of 8 can be sufficient in term of the later created cropping surface. Number of branches increased with cv. 'Petrus' with $36 \%$ (4.4-6.0 piece), as cv. 'Carmen' showed 16\% growth (5.05.8 piece) in two years.

Primary branches on bush canopy are thicker with all cultivar, than on slender spindle crown form. Scale of the thickening is also larger on bush canopy. It was the most obvious with cv. 'Vera' (6.3-11.4 $\left.\mathrm{cm}^{2}\right)$, which means $80 \%$ change. Cultivar 'Carmen' showed $45 \%$ increase, as cv. 'Petrus' presented $10 \%$ increment.

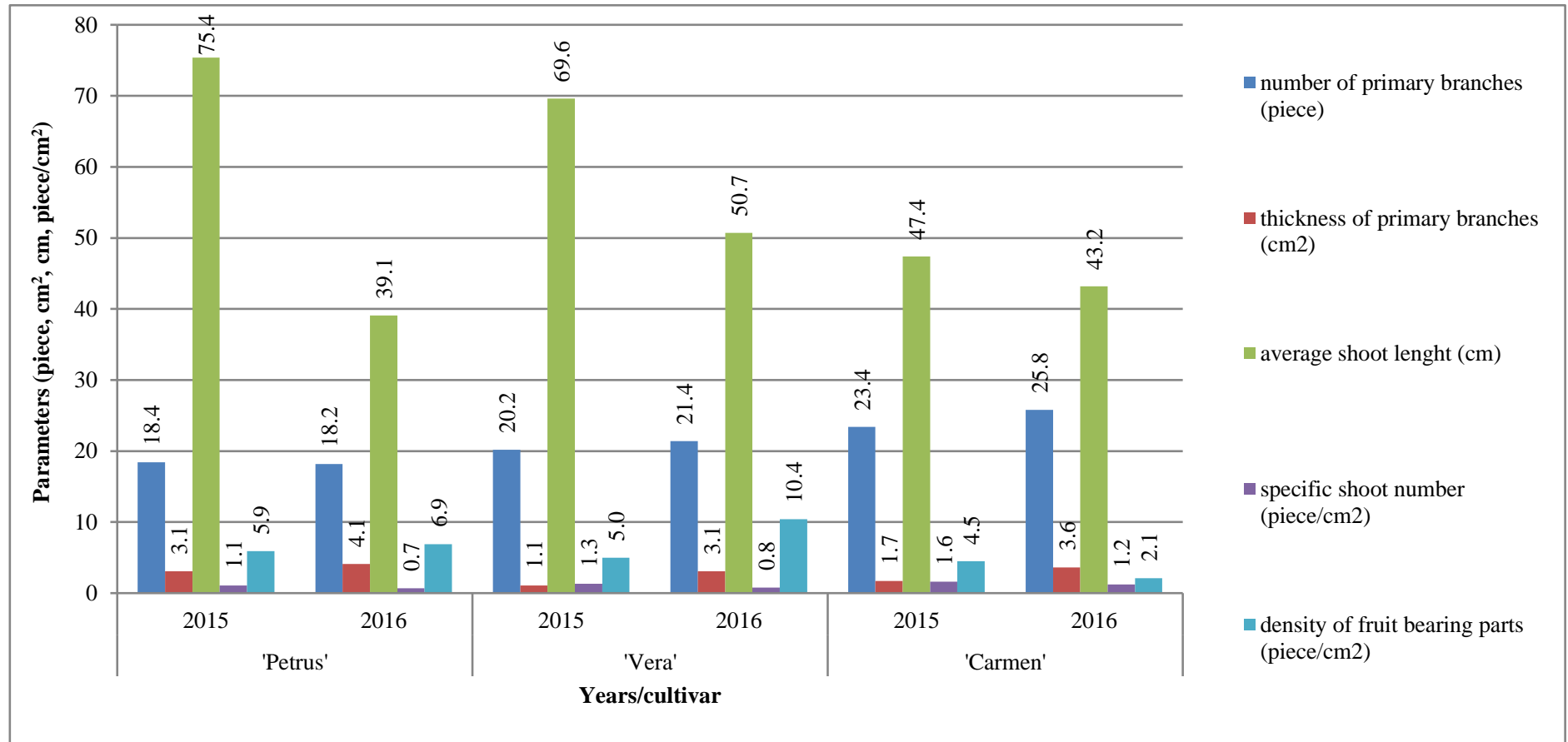

Figure 4. Parameters of shoots, branches and fruit bearing parts on slender spindle canopy (Debrecen - Pallag, 2015-2016) 


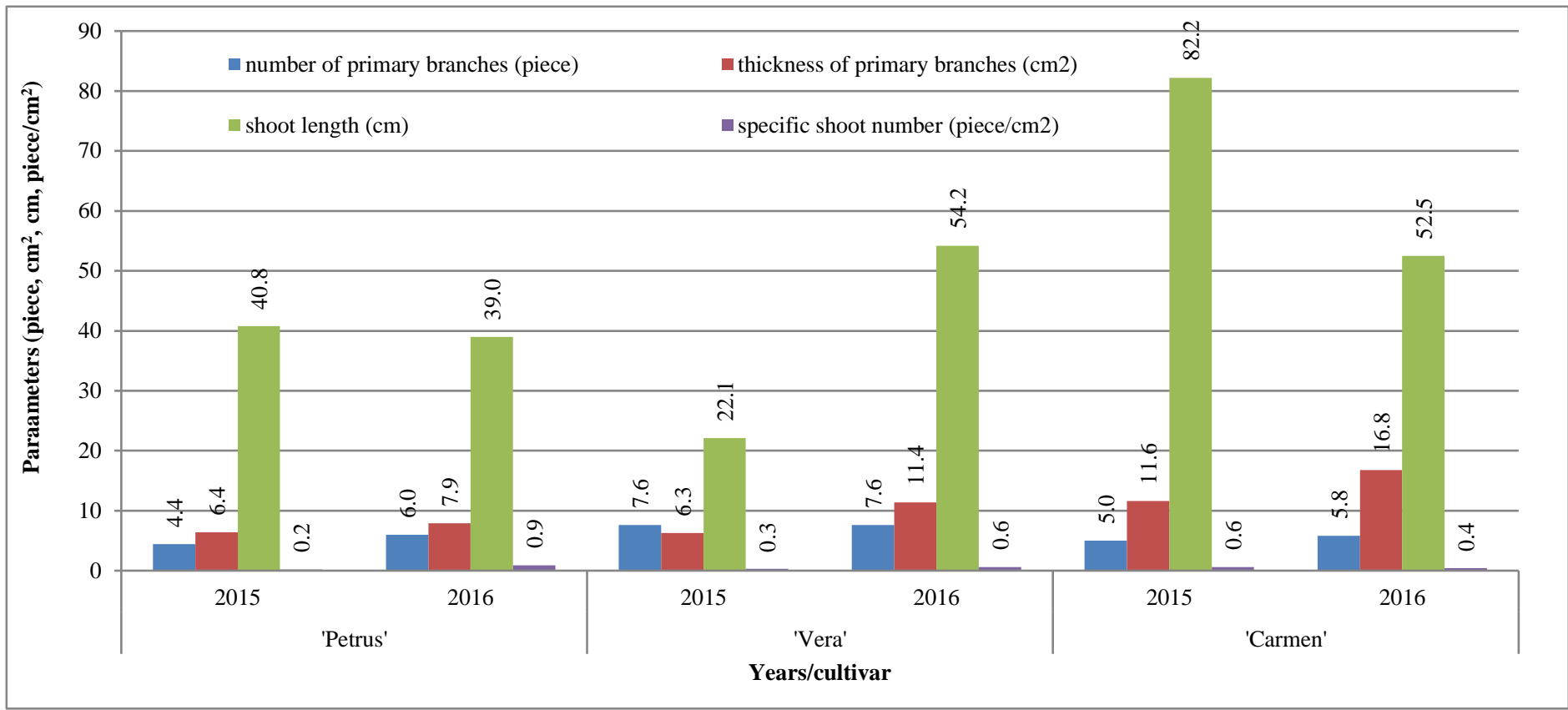

Figure 5. Parameters of shoots and branches on Spanish bush canopy (Debrecen - Pallag, 2015-2016)

Decline in vegetative growth for this canopy is not appeared yet, which is manifested in the length of the shoots. Slender spindle canopy presented decreasing tendency, while average shoot length of bush canopy is still growing with certain cultivars. Values of cv. 'Petrus' are more balanced (41$39 \mathrm{~cm})$, as cv. 'Vera' can be described with long shoots $(22-54$ $\mathrm{cm})$ despite that the number of the shoots grew also. At the same time shoots of cv. 'Carmen' are shorter with 37\% in 2016 $(82-53 \mathrm{~cm})$.

Specific shoot number was between 0.2 and 0.6 piece $/ \mathrm{cm}^{2}$ in 2015. For cv. 'Carmen' with an average branch thickness of $11.6 \mathrm{~cm}^{2}$ this means 7 shoots per branch (11.6*0.6). In 2015 values of cultivars are between $0.4-0.9$ piece $/ \mathrm{cm}^{2}$. Cultivar 'Petrus' showed the highest specific shoot number (0.9 piece $/ \mathrm{cm}^{2}$ ).

\section{References}

Balmer, M., Blanke, M. M. (2005): Developments in high density cherries in Germany. Acta Horticulturae 667: 273-277. https://doi.org/10.17660/ActaHortic.2005.667.40

Bicskei D, K., Gonda, I. (2014). Comparative analysis of different canopy forms of sweet cherry cultivars. Acta Agraria Debreceniensis (56): 19-22. DOI: https://doi.org/ 10.34101/actaagrar/56/1926

Bujdosó, G. (2006): Cseresznyetermesztés Spanyolországban. Kertgazdaság. 38(4): 109-114.

Csihon, Á. (2015): Új almafajták növekedési, terméshozási és gyümölcsminőségi tulajdonságainak vizsgálata. Doktori értekezés. DE MÉK. 173. pp.

Csihon, Á., Holb, I., Gonda, I. (2015): Growing characteristics of apple cultivars and canopies. International Journal of Horticultural Science 21(1-2): 7-10. https://doi.org/10.31421/IJHS/21/1-2./1150
Gonda, I., Király, K., Holb, I. (2007): Examination of growth of cherry cultivars adapted to intensive production. Acta Horticulturae 732: 429-434. https://doi.org/10.17660/ ActaHortic.2007.732.64

Hrotkó K. (2003): A cseresznye és a meggy művelési rendszerei. In: Cseresznye és meggy. Edited: Hrotkó K. Mezőgazda Kiadó. Budapest. 152-169.

Hrotkó, K., Magyar, L., Simon, G., Gyeviki, M. (2007): Development in intensive orchard systems of cherries in Hungary. International Journal of Horticultural Science, 13(3): 76-86. https://doi.org/10.31421/IJHS/13/3/751

Negrón, C., Lemus, G., Valenzuela, J. (2001): Comparison among Solaxe and Spanish bush training systems for Rainier and Van sweet cherries in the Chilean central zone growing area. Acta Horticulturae 667. 373-378.

Soltész, M., Szabó, Z., Nyéki, J. (2000): Training systems of fruit trees in Hungary. International Journal of Horticultural Science, 6(1): 123-127. https://doi.org/10.31421/IJHS/6/1/82.

Tomcsányi, P. (1973): Piacos kertészet. Mezőgazdasági Kiadó, Budapest. 632. pp.

Vaszily, B., Gonda, I. (2010): Training and maintaining spindle crowns in cherry production. International Journal of Horticultural Science, 16(3): 51-53. https://doi.org/ 10.31421/IJHS/16/3/896

Whiting, M.D., Lang, G., Ophardt, D., (2005): Rootstock and training system affect sweet cherry growth, yield, and fruit quality. HortScience 40: 582-586. https://doi.org/ 10.21273/HORTSCI.40.3.582

Zahn, F. G. (1996): Close planting in relation to low orchard height. Horticultural Science 28(1-2): 58-66. 